\title{
REVIEW
}

\section{GPCR transactivation signalling in vascular smooth muscle cells: role of NADPH oxidases and reactive oxygen species}

\author{
Raafat Mohamed 1,6, Reearna Janke1, Wanru Guo', Yingnan Cao², Ying Zhou', Wenhua Zheng', \\ Hossein Babaahmadi-Rezaei ${ }^{4}$, Suowen $\mathrm{Xu}^{5}$, Danielle Kamato ${ }^{1,2}$ and Peter J Little ${ }^{1,2}$ \\ 'School of Pharmacy, Pharmacy Australia Centre of Excellence, The University of Queensland, Woolloongabba, Queensland, Australia \\ 2Department of Pharmacy, Xinhua College of Sun Yat-sen University, Guangzhou, China \\ ${ }^{3}$ Faculty of Health Sciences, University of Macau, Taipa, Macau, China \\ 4Department of Clinical Biochemistry, Faculty of Medicine, Ahvaz Jundishapur University of Medical Sciences, Atherosclerosis Research Center, Ahvaz, Iran \\ ${ }^{5}$ Department of Medicine, Aab Cardiovascular Research Institute, University of Rochester School of Medicine and Dentistry, Rochester, New York, USA \\ ${ }^{6}$ Department of Basic Sciences, College of Dentistry, University of Mosul, Mosul, Iraq
}

Correspondence should be addressed to P J Little: p.little@uq.edu.au

\begin{abstract}
The discovery and extension of G-protein-coupled receptor (GPCR) transactivationdependent signalling has enormously broadened the GPCR signalling paradigm. GPCRs can transactivate protein tyrosine kinase receptors (PTKRs) and serine/threonine kinase receptors (S/TKRs), notably the epidermal growth factor receptor (EGFR) and transforming growth factor- $\beta$ type 1 receptor (TGFBR1), respectively. Initial comprehensive mechanistic studies suggest that these two transactivation pathways are distinct. Currently, there is a focus on GPCR inhibitors as drug targets, and they have proven to be efficacious in vascular diseases. With the broadening of GPCR transactivation signalling, it is therefore important from a therapeutic perspective to find a common transactivation pathway of EGFR and TGFBR1 that can be targeted to inhibit complex pathologies activated by the combined action of these receptors. Reactive oxygen species (ROS) are highly reactive molecules and they act as second messengers, thus modulating cellular signal transduction pathways. ROS are involved in different mechanisms of GPCR transactivation of EGFR. However, the role of ROS in GPCR transactivation of TGFBR1 has not yet been studied. In this review, we will discuss the involvement of ROS in GPCR transactivation-dependent signalling.
\end{abstract} Key Words

- GPCR

- transactivation

- G protein

- TGF-beta

- epidermal growth factor

\section{Introduction}

G-protein-coupled receptors (GPCRs) are amongst the most numerous receptors in biology and they represent the largest single class of targets for therapeutic agents (1, 2 ). GPCRs are responsible for fundamental physiological processes and they are also involved in numerous pathophysiological states (3). GPCR signalling was first described as what is now referred to as classic or linear cell signalling involving transmembrane receptors, G proteins, effector molecules and response elements $(4,5)$. Activation of the GPCR by ligands results in the replacement of bound GDP by GTP on the G $\alpha$ subunit followed by dissociation of GTP-bound $\mathrm{G} \alpha$ from G $\beta \gamma$ subunit and each interact with a variety of effectors including adenylyl cyclase, ion channels and phospholipase C (PLC) leading to increases (c) 2019 The authors Published by Bioscientifica Ltd 
of cyclic adenosine monophosphate (cAMP), calcium and protein kinase $\mathrm{C}$ (PKC) activity $(6,7,8)$.

In addition to this classic/linear signalling, GPCRs can transactivate other cell-surface receptors notably protein tyrosine kinase receptors (PTKRs) including receptors for epidermal growth factor (EGF) (9), platelet-derived growth factor (PDGF) (10) and fibroblast growth factor (FGF) (11). Transactivation greatly expands the cellular responses that can be generated by GPCRs. The initial cellular signalling process defined as transactivation was identified as lysophosphatidic acid (LPA) acting via its GPCR leading to phosphorylation of the downstream ERK (and an increase in cellular phosphoERK); this response was blocked by the EGF receptor (EGFR) antagonist, AG1478, indicating that it arises from transactivation of the EGFR (9). Since the original observations, this paradigm has recently been expanded to include the transactivation of serine/threonine kinase receptors (S/TKR) notably transforming growth factor (TGF)- $\beta$ type 1 receptor (TGFBR1). In human vascular smooth muscle cells (VSMCs), treatment with thrombin (12, 13) or endothelin-1 (ET-1) $(14,15)$ stimulates carboxy terminal phosphorylation of the transcription factor Smad2. This response was blocked by the TGFBR1 antagonist, SB431542, indicating that the response arises from GPCR transactivation of TGFBR1 $(13,14,16,17)$. GPCR transactivation of S/TKR or PTKR modulates gene transcription, cell migration and proliferation, secretion of hormones, cytokines and matrix molecules and changes in cellular phenotype $(13,18,19)$.

Reactive oxygen species (ROS) are highly chemically reactive species arising from multiple metabolic and enzymatic sources inside all cells (20). ROS play a role in S/TKR- and PTKR-mediated signalling pathways (21, 22, 23) and in the GPCR transactivation of growth factor receptors $(24,25)$. Therefore, understanding the role of ROS in GPCR transactivation signalling of both S/TKR and PTKR may reveal a common therapeutic target for all GPCR transactivation-dependent signalling.

ROS are known to be involved in GPCR transactivation of PTKR $(24,25,26)$ but much less is known of the role of ROS in GPCR transactivation of S/TKR. The current knowledge of the mechanisms of GPCR transactivation of PTKR and S/TKR reveal that these occur by completely different biochemical mechanisms and signalling pathways $(13,16)$. For example, matrix metalloproteinases (MMPs) are involved in GPCR transactivation of PTKR, but they are not involved in transactivation of $\mathrm{S} / \mathrm{TKR}$ which is a process reliant upon Rho/ROCK activation (13, 16). These differences increase the opportunities for ROS as a common intermediate for all GPCR transactivationdependent signalling and these issues are addressed in this review.

\section{ROS - source and role in cell biology}

ROS serve as second messengers to modulate signal transduction and gene expression (27). ROS can be produced by a variety of systems, including nicotinamide adenine dinucleotide phosphate (NADPH) oxidase (Nox), xanthine oxidase, uncoupled endothelial nitric oxide (eNOS) and assorted enzymes in the mitochondrial respiratory chain $(28,29,30)$. Common examples of ROS include superoxide anion $\left(\cdot \mathrm{O}_{2}^{-}\right)$, hydrogen peroxide $\left(\mathrm{H}_{2} \mathrm{O}_{2}\right)$, hydroxyl radical $(\cdot \mathrm{OH})$, nitric oxide $(\cdot \mathrm{NO})$ and peroxynitrite $\left(\mathrm{OONO}^{-}\right)(31,32)$.

In mammals, the Nox family is composed of seven isoforms including Nox1-5 and dual oxidase (Duox) 1 and 2 (33). The main function of Nox is to produce ROS (34). Of the seven Nox isoforms only 4 (Nox1, Nox2, Nox4 and Nox5) catalytic homologues are expressed in VSMCs $(35,36)$. Nox 1 and Nox 4 are the main sources of ROS in VSMCs $(37,38)$. Nox consists of several subunits (membrane-bound and cytosolic) and their enzymatic activity requires recruitment of cytosolic subunits to the membrane-bound subunits forming a functional enzyme complex which utilises NADPH as an electron donor leading to the formation of superoxide from molecular oxygen (39). In VSMCs, the activity of Nox1 requires the binding of the activator subunit (Noxo1) and the organiser p47phox to the membrane-bound p22phox (39). Nox2 can be activated by association of the cytosolic subunits (p47phox, p67phox and a small GTPase, Rac-1) with the membrane-bound components (40). Nox4 activity can be regulated by binding of poldip2 with the p22phox subunit (41). Nox5 is activated by intracellular calcium binding $(35,42)$. Overexpression or increased expression of one subunit is usually accompanied by an increase in expression of others, resulting in an overall increase in Nox-mediated ROS production (31). Unlike Nox4 that mainly generates hydrogen peroxide, Nox1 and Nox2 generate superoxide (37).

The superoxide anion is produced by a one electron reduction of molecular oxygen via Nox. This unpaired electron renders superoxide anions biochemically unstable and short-lived (43). Therefore, superoxide rapidly converts to hydrogen peroxide either spontaneously or catalysed by the cytoplasmic superoxide dismutase (SOD) (44). However, the excess in the level of superoxide

This work is licensed under a Creative Commons Attribution-NonCommercial-NoDerivatives 4.0 International License. International License.
ded from Bioscientifica.com at 04/26/2023 09:46:44AM 
anion reacts with nitric oxide leading to peroxynitrite formation (45). Hydrogen peroxide, the main biological ROS (46) is produced by dismutation of superoxide and xanthine oxidase enzyme (47). ROS research has focused on hydrogen peroxide because it is highly reactive, more stable than superoxide anion and can easily diffuse across cell membranes (48). In the presence of ferrous ions $\left(\mathrm{Fe}^{2+}\right)$, hydrogen peroxide can be converted to hydroxyl radical (49). A second possible fate of hydrogen peroxide occurs when myeloperoxidase (MPO) enzyme converts hydrogen peroxide to hypochlorous acid. As a protective mechanism, cells throughout the body use catalase to convert hydrogen peroxide to water (50).

ROS at high concentrations can induce damage to proteins, lipids and nucleic acids (51). However, at low levels, ROS are known to play a critical role in cellular signalling such as regulation of ion channels, protein phosphorylation and transcription factors (50). ROS can be homeostatically maintained at low physiological levels by antioxidant compounds which include enzymes such as SOD, glutathione peroxidase (GPx), catalase and peroxiredoxin and non-enzymatic compounds such as glutathione (GSH) and ascorbic acid (52). The antioxidant compounds are responsible for attenuating the harmful effects of ROS overproduction and ameliorating oxidative stress (53). However, preventing ROS overproduction has been proposed as a superior approach in the treatment of vascular diseases (34).

\section{The role of ROS and Nox in the classic GPCR signalling}

GPCR agonists, angiotensin II (AngII) (54), LPA (55), ET-1 (56) and thrombin (57) all induce ROS generation in VSMCs. As a secondary messenger, ROS can directly elicit various downstream signalling cascades, including the Ras/mitogen-activated protein kinase (MAPK) and phosphoinositide 3-kinase (PI3K)/protein kinase B (Akt) pathways thus regulating multiple cellular processes such as differentiation, proliferation, migration and cell survival (58). In rat neonatal cardiomyocytes, hydrogen

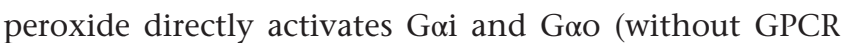
involvement) causing the liberation of $\beta \gamma$-subunit that leads to PI3K activation, which in turn stimulates Akt and ERK (59). The in vitro study of cardiomyocytes from neonatal rats showed that ROS activates both ERK and p38 MAPK (60). Hydrogen peroxide dose dependently stimulates the phosphorylation of ERK via Src family tyrosine kinases and the Ras-dependent pathway. Inhibition of MAPK phosphorylation plays a central role in preventing the apoptosis of these cells following oxidative stress (60).

Long-term treatment with vasoactive hormone AngII simulates Nox activity which leads to superoxide anion production and VSMC hypertrophy by AngII, which was attenuated by diphenyleneiodonium (DPI) (54). AngII stimulates ROS generation in human VSMCs via the intracellular phospholipase D (PLD) signalling pathway. Partial inhibition of AngII-mediated hydrogen peroxide production by two selective PKC inhibitors (calphostin C and chelerythrine chloride) suggests that other pathways are involved in AngII-mediated ROS production (61). In addition, PLC- $\beta$-mediated PKC activation has been implicated in Phorbol 12,13-dibutyrate (PDBu)-induced Nox-dependent ROS production to promote VSMC contraction (62). Selective PKC inhibitors GF109203X, staurosporine, chelerythrine and calphostin C inhibit PDBu-mediated ROS production to the same degree as DPI in bovine coronary arteries (62). Treatment with the PKC inhibitors and DPI inhibited PDBu induced coronary artery contractions. Other possible explanations of ROS generation involve the AngII activation of PLC, PLD and phospholipase A2 (PLA2) (63), amongst them, PLA2 releases arachidonic acid which in turn activates production of ROS in VSMCs (64). PLC activated by PIP2 triggers the IP3- $\mathrm{Ca}^{+2}$ pathway, and DAG activates PKC, both participating in the activation of Nox complex (54). PLD also causes production of PA and increases DAG production, which also activates PKC and Nox (61). Alternatively, PIP3 produced by PKC-activating RhoGEF, activates Rac-1 and Nox1-generated ROS (65).

Thrombin induces c-Src activation through the GPCR, protease-activated receptor-1 (PAR-1) to induce interleukin 8 expression in epithelial cells (66). The activation of c-Src phosphorylates p47phox, allowing the glycoprotein to change conformation from its auto-inhibitory resting state and translocate to the membrane. Once at the membrane, p47phox can interact with membrane-bound and cytosolic subunits of Nox and organise the assembly of the active enzyme $(67,68,69)$. The fundamental role of ROS in classic GPCR signalling provides encouraging evidence to study the role of ROS in GPCR transactivation of other cell-surface receptors notably PTKRs and S/TKRs.

\section{The role of Nox/ROS in GPCR transactivation of EGFR}

Activation of EGFR triggers various signalling cascades which regulates/multiple cell functions such as cell

This work is licensed under a Creative Commons Attribution-NonCommercial-NoDerivatives 4.0 International License. ded from Bioscientifica.com at 04/26/2023 09:46:44AM 
growth and development, proliferation, cytoskeleton reorganisation and motility (70, 71). EGF induces ROS (hydrogen peroxide) generation in A431 human epidermoid carcinoma cells (72). A transient increase of intracellular ROS by EGF was inhibited when EGFR phosphorylation was inhibited by catalase (72). In rat VSMCs, PI3K produces PIP3 which converts Rac-1 to its GTP-bound active form. Activated Rac-1 translocates and binds to the cytosolic Nox subunit p47phox that is attached to membrane-anchored subunits, resulting in Nox activation (73). EGF stimulates ROS production via PI3K/Src-dependent pathways to promote invasion in pancreatic cancer cells (21).

In human epithelial cells, prevention of EGF-induced ROS formation by N-acetyl-L-cysteine (NAC) inhibits the phosphorylation of Akt, ERK1/2 and c-Jun N-terminal kinase (JNK) (74). Consistent with these results, in renal epithelial cells, EGFR-mediated ROS production leads to phosphorylation of ERK1/2 (75). However, in primary human fibroblasts, both ROS and ERK1/2 regulate each other's activity in a vicious cycle (76). The mechanism by which ROS regulates MAPK remains unclear; however, several studies $(77,78,79)$ propose that ROS-mediated MAPK activation occurs indirectly via inhibition of MAPK phosphatase via reversible oxidation of catalytic-site cysteine to produce sulfenic acid.

The ligand-dependent triple membrane passing HB-EGF-dependent signalling mechanism represents one of the best known mechanisms of GPCR transactivation of PTKR. This process involves stimulation of GPCR and activation of a MMP or A Disintegrin and A Metalloprotease (ADAM) resulting in cleavage and release of a membraneanchored pro-heparin-binding-EGF (pro-HB-EGF). Subsequently, the free HB-EGF binds and activates EGFR in an autocrine and paracrine manner $(80,81)$. We have previously observed in human VSMCs, thrombin via its receptor PAR-1 stimulated the phosphorylation of ERK (16), and EGFR (13) was inhibited by broad-spectrum MMP inhibitor, GM6001, thus demonstrating the involvement of the triple membrane passing mechanism in PAR-1 transactivation of PTKR.

GPCR transactivation of EGFR can also occur via Nox/ROS-dependent mechanisms (Fig. 1) (26). The involvement of ROS in GPCR transactivation of EGFR has been extensively studied using the GPCR agonists such as AngII, LPA and thrombin $(82,83,84,85)$. AngII-induced phosphorylation of EGFR and ERK1/2 in cardiac fibroblasts was attenuated by ROS scavenger NAC in a dose-dependent manner (25). AngII stimulated hypertrophy of VSMCs is mediated by Nox-derived ROS production (86). Pharmacological inhibitors, to PLC, PI3K, c-Src, Rac, were involved in AngII-induced Nox activation. This was followed with the finding that c-Src is required for the assembly of Nox and PKC activated by PLC is required for phosphorylation of a serine residue in p47phox (87) and is responsible for the first phase of ROS generation (86). As the upstream mediator of ROS generation, these proteins are deeply involved in ROSmediated EGFR transactivation, especially c-Src (88) which phosphorylates EGFR on Y845 site (89). AngII induced EGFR Tyr1068 and Tyr1173 phosphorylation in a c-Srcand $\mathrm{Ca}^{+2}$-dependent manner in VSMCs, overexpression of kinase-inactive c-Src or chelation of intracellular $\mathrm{Ca}^{+2}$ attenuated EGFR transactivation (90).

In cardiomyocytes, silencing of Nox4 inhibited ADAM17 expression in AngII transactivation of EGFR (19). AngII stimulates an increase in ADAM17 expression which induces the release of mature HB-EGF to activate EGFR and stimulate cardiac hypertrophy. Furthermore, AngII increased intracellular levels of ROS in rat VSMCs (91)

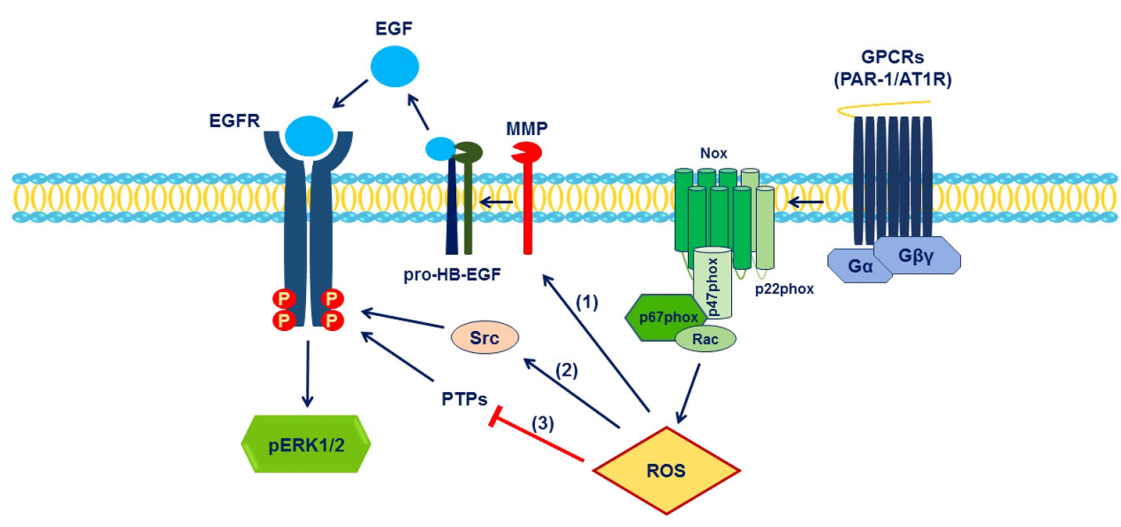

https://vb.bioscientifica.com https://doi.org/10.1530/VB-18-0004 (c) 2019 The authors Published by Bioscientifica Ltd

\section{Figure 1}

Schematic representation of known and speculated roles of NADPH oxidase (Nox) and ROS in G-protein-coupled receptor (GPCR) transactivation of epidermal growth factor receptor (EGFR). GPCR transactivation of EGFR occurs via an increase in intracellular reactive oxygen species (ROS) which in turn (1) activate matrix metalloproteinase (MMP) that cleaves heparin-binding EGF-like growth factor (pro-HBEGF) and release the EGF ligand leading to EGFR activation and subsequently phosphorylation of downstream intermediate extracellular signalregulated kinase1/2 (ERK1/2). GPCR stimulation of ROS activates the EGFR (2) via Src-dependent pathway and (3) through inhibition of protein tyrosine phosphatases (PTPs). 
via Nox1 (38). More recently, in rat aortic VSMCs, AngII through angiotensin type 1 receptor (AT1R) activated ADP-ribosylation factor 6 (ARF6), a small GTPase, followed by activation of Rac1 leading to the upregulation of Nox1 and its product ROS ultimately resulting in enhanced cell proliferation. Using a pharmacological and molecular approach, AngII can signal via AT1R/ARF6/Rac1/ Nox1/ROS/EGFR axis (92). AngII signals via $\beta$-arrestin to regulate ARF6 activation and subsequent receptor endocytosis and ultimate cell migration of rat aortic VSMCs (93). These observations suggest the involvement of $\beta$-arrestin and ARF6 in AT1R-initiated ROS-dependent EGFR transactivation. In addition, caveolin-1 (Cav1) is essential for AT1R-mediated Rac1 activation, which is associated with AngII-mediated ROS-dependent EGFR transactivation and as a consequence VSMC hypertrophy (94). The data reviewed above indicate a role of ROS in GPCR transactivation of the EGFR (Fig. 1); however, the precise mechanism by which ROS exerts its effects has not been fully elucidated.

\section{The role of Nox/ROS in GPCR transactivation of TGFBR1}

TGF- $\beta$ is a pleiotropic growth factor and serves as a key molecule in the regulation of a broad diversity of cellular functions including cell proliferation, differentiation, migration and extracellular matrix synthesis (95). TGF- $\beta$ family ligands exert their signal transduction by binding to cell-surface receptors, with predominantly intrinsic serine/threonine kinase activity. TGF- $\beta$ via its cognate receptor transduces signals via Smad-dependent and Smad-independent pathways (96, 97, 98, 99). Here we discuss how ROS interferes with Smad-dependent and -independent signalling pathways to regulate downstream gene expression. Many studies have documented that TGF- $\beta$ generates ROS production in a wide variety of cell types including human airway smooth muscle cells (100), human lung fibroblasts (101), rat hepatocytes (102), pancreatic cancer cells (103) and VSMCs (22).

In our recent work, we have shown that although canonical TGF- $\beta$-mediated Smad2 carboxy terminal phosphorylation is ROS independent, the phosphorylation of the Smad2 linker region by TGF$\beta$ occurrs via ROS-dependent pathway in human VSMCs (22). Pharmacological inhibition of ROS/Nox with NAC, DPI and apocynin has no effect on carboxy terminal phosphorylation of Smad2 (data not published). However, DPI and apocynin prevent TGF- $\beta$-induced phosphorylation of Smad2 linker region (22). Transfection of human pulmonary artery SMCs with dominant negative Smad2 and Smad3 blocked Nox4 gene expression and ROS production caused by TGF- $\beta$, suggesting that TGF- $\beta$ triggers Nox4-derived ROS generation via the Smad2/3 pathway (104). Attenuation of ROS formation by Nox4 siRNA inhibits TGF- $\beta$-mediated Smad3 phosphorylation in cardiac fibroblasts, indicating that Nox4 is upstream of TGF- $\beta /$ Smad3 pathway (105).

MAPKs are downstream components of TGF- $\beta$ signalling $(106,107)$. In human VSMCs, TGF- $\beta$ mediated ROS production leads to the activation of MAPK, ERK and p38 (22). Antioxidants, NAC and catalase, suppress ROS production by TGF- $\beta$ and inhibit the phosphorylation of ERK1/2 and p38 in rat renal epithelial cells, resulting in the prevention of TGF- $\beta$-induced epithelial-mesenchymal transition (23). TGF- $\beta$ generated ROS is responsible for prevention of HSC-T6 cell proliferation by reducing MAPK stimulation. Dihydrolipoic acid, a potent antioxidant, inhibits TGF- $\beta$-stimulated ERK1/2 and JNK phosphorylation (108). ROS can also oxidise and in turn inactivate specific MAPK phosphatases (MAP-1 and MAP-3) causing indirect activation of MAPK (78). Activation of pulmonary artery smooth muscle cells with TGF- $\beta$ upregulates Nox4 gene expression and ROS production. The PI3K inhibitor, LY294402 supressed the gene expression of Nox4 indicating the PI3K/Akt pathway is essential in TGF- $\beta$-mediated Nox4-dependent cell proliferation (109).

The phenomenon of GPCR transactivation signalling was expanded approximately a decade ago to include activation of S/TKR notably the TGFBR1. GPCR transactivation of the TGFBR1 occurs via completely different mechanisms as compared to EGFR transactivation. GPCR transactivation of the TGFBR1 involves cytoskeletal rearrangement which activates ROCK signalling leading to the activation of integrin dependent signalling. Activated integrin binds to the large latent TGF- $\beta$ complex (LLC) causing conformational changes in LLC, which exposes the TGF- $\beta$ ligand (16) (Fig. 2). The role of ROS in GPCR transactivation of the TGFBR1 has not yet been explored; however, ROS regulates ROCK and integrins.

Recently, we have found that the endogenous pharmacological stimulation of ROS in human VSMCs activates ROCK, and ROCK inhibitor, Y27632, inhibits ROS-dependent phosphorylation of Smad2 carboxy terminal (data not published). In rat SMC arteries, ET-1 increased calcium sensitisation via ROS-dependent Rho/ ROCK signalling pathway. (110). However, in human oesophageal adenocarcinoma cells, ROCK2 is upstream

This work is licensed under a Creative Commons Attribution-NonCommercial-NoDerivatives 4.0 International License. ded from Bioscientifica.com at 04/26/2023 09:46:44AM 


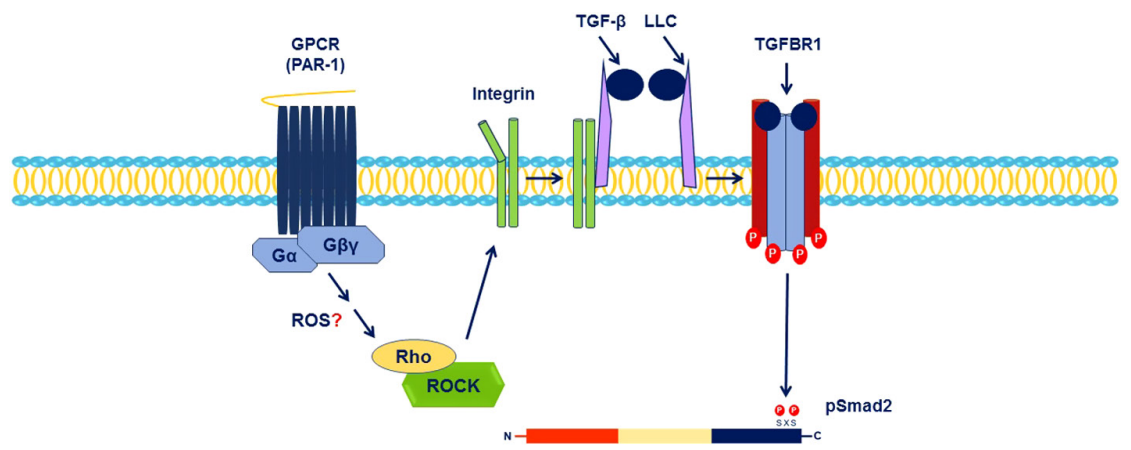

Figure 2

Schematic representation of the mechanism of G-protein-coupled receptor (GPCR) transactivation of transforming growth factor- $\beta$ type 1 receptor (TGFBR1). GPCR transactivation of TGFBR1 occurs via cytoskeletal rearrangement which activates Rho-associated protein kinase (RhoA/ROCK) signalling and cell-surface integrin. Activated integrin binds to and activates the large latent TGF- $\beta$ complex (LLC), leading to the subsequent phosphorylation of the downstream intermediate Smad2 in the carboxy terminal.

of Nox5-derived ROS (111). These findings suggest that ROCK signalling is a redox-sensitive pathway and GPCR generation of ROS could play a major role in GPCR transactivation of TGFBR1 via ROCK signalling.

ROS is also known to activate different integrins including integrin $\alpha 2$, integrin $\alpha 6$ and integrin $\beta 3$, where hydrogen peroxide upregulates the gene expression of integrins in epithelial cells (112). ROS are involved in integrin activation and integrins are involved in transactivation of TGFBR1; however, the role of ROS in GPCR transactivation of TGFBR1 has not been investigated. Hence, although ROS involvement in GPCRmediated transactivation of PTKRs such as EGFR is well known, the role of ROS in TGFBR1 transactivation by GPCR will be a completely novel area of investigation.

\section{Conclusion}

ROS are involved in physiological and pathophysiological actions of VSMCs, including proliferation, secretion of inflammatory cytokines, extracellular matrix production, contraction and differentiation (65). Oxidative stress is the one of the major contributors to the pathophysiology of many diseases, including cardiovascular diseases (CVDs) such as atherosclerosis (113). Atherosclerosis is a chronic inflammatory disorder characterised by lipids and fibrous element accumulation over many years, in medium to large blood vessels (114). Atherosclerosis represents the major underlying aetiology of most CVDs including coronary artery disease, stroke, cerebrovascular disease and peripheral artery disease (Lusis et al. 2004). There are three major mechanisms by which ROS are proposed to induce CVDs, oxidation of low-density lipoprotein (LDL), inhibition of nitric oxide vasodilation and intracellular signalling activation via ion channels, protein phosphorylation and transcription factors (27, 115). VSMCs are involved in all stages of atherosclerotic plaque development. With the early development of atherosclerosis, VSMCs lose contractility increase proliferation and increase proteoglycan expression (116, 117) and in advanced stages of disease dedifferentiated VSMCs proliferate and migrate contributing to the fibrous cap and stabilising the plaque.

Several clinical studies of antioxidants have been unsuccessful in improving cardiovascular events in moderate-to-high-risk patients $(118,119)$. For instance, the Heart Outcomes Prevention Evaluation (HOPE) study demonstrated that up to 6 years of daily intake of vitamin $\mathrm{E}$ had no beneficial effects on cardiovascular outcomes in high-risk patients (120). One of potential reasons of antioxidant limitations is the difficulties of targeting precise intracellular signalling pathways which leading to the oxidative stress (121). Thus, there is a need to further investigate which signalling pathways disrupted by high levels of ROS leading to the development of atherosclerosis might represent preferred targets for preventing the pathophysiological actions of ROS.

The GPCR signalling paradigm has been expanded to include GPCR transactivation of PTKRs and S/TKRs notably EGFR and TGFBR1, respectively. While GPCR transactivation of EGFR requires MMP stimulation, the activation of TGFBR1 occurs through cytoskeletal rearrangement which activates ROCK signalling and cellsurface integrins $(13,16,122)$. We previously found that the GPCR agonist thrombin transactivates the EGFR and TGFBR1 to stimulate the expression of enzymes involved in the hyperelongation of glycosaminoglycan chains on the proteoglycan, biglycan $(123,124)$ which is associated with increased lipid retention in the vessel wall initiating atherosclerosis $(125,126)$. We have described that GPCR transactivation of either receptor is occurring via completely different mechanisms and the identification of a common mechanism can attenuate all GPCRmediated GAG chain elongation $(127,128)$. However, established data for GPCR transactivation of PTKRs and newly emerging data for mechanisms of S/TKRs indicates that ROS may be involved in both transactivation 
mechanisms and as such ROS would represent the first common mechanism and hence the first potential target to prevent all transactivation signalling.

The relevance of this work relates to the role of ROS in accelerating atherosclerosis and promoting CVDs and the potential of targeting ROS-related mechanisms to prevent CVD. Clinical trials of a broad range of antioxidants have been unsuccessful in demonstrating a benefit occurring as a reduction in CVD events in the treated cohort. This has been the topic of considerable controversy for many years with multiple credible and substantive proposals offered to provide explanations for the failed efficacy of antioxidant strategies (129). These explanations relate to the chemistry and pharmacokinetics of antioxidants and generally the complexity of the regulation of the redox state of cell and its impact on cellular functioning.

We are proposing that a deeper understanding of the impact of redox state and also the role of ROS in cellular signalling of the processes associated with the initiation and progression of atherosclerosis is required such that a more specific target may be identified. ROS and specifically their downstream signalling pathways may be identified as a superior therapeutic target compared to the somewhat blunt use of high-dose antioxidants. This concept is presented in the context of GPCR transactivation of cellsurface kinase receptors as a recently expanded paradigm of GPCR signalling whose therapeutic potential is not yet to be fully understood.

\section{Declaration of interest}

The authors declare that there is no conflict of interest that could be perceived as prejudicing the impartiality of this review. Professor P Little is a Senior Editor of Vascular Biology. Dr D Kamato is an Early Career Researcher on the Editorial Board of Vascular Biology. Professor Little and Dr Kamato were not involved in the review or editorial process for this paper, on which they are listed as authors.

\section{Funding}

R M was supported by the University of Mosul, Iraq. Support was received from the University of Queensland through a personal support package to P J L and by the University of Queensland Early Career Grant (D K) (grant no. 1832825). D K is supported by NHMRC-Peter Doherty (1160925) and National Heart Foundation (102129) Fellowships.

\section{References}

1 Klabunde T \& Hessler G. Drug design strategies for targeting G-protein-coupled receptors. ChemBioChem 20023 928-944. (https://doi.org/10.1002/1439-7633(20021004)3:10<928::AIDCBIC928>3.0.CO;2-5)
2 Mcneely PM, Naranjo AN \& Robinson AS. Structure-function studies with $\mathrm{G}$ protein-coupled receptors as a paradigm for improving drug discovery and development of therapeutics. Biotechnology Journal 20127 1451-1461. (https://doi.org/10.1002/biot.201200076)

3 Marinissen MJ \& Gutkind JS. G-protein-coupled receptors and signaling networks: emerging paradigms. Trends in Pharmacological Sciences 200122 368-376. (https://doi.org/10.1016/S01656147(00)01678-3)

4 Kamato D, Rostam MA, Bernard R, Piva TJ, Mantri N, Guidone D, Zheng W, Osman N \& Little PJ. The expansion of GPCR transactivation-dependent signalling to include serine/threonine kinase receptors represents a new cell signalling frontier. Cellular and Molecular Life Sciences 201572 799-808. (https://doi.org/10.1007/ s00018-014-1775-0)

5 Lefkowitz RJ. Historical review: a brief history and personal retrospective of seven-transmembrane receptors. Trends in Pharmacological Sciences 200425 413-422. (https://doi.org/10.1016/j. tips.2004.06.006)

6 Brown DA \& Sihra TS. Presynaptic signaling by heterotrimeric G-proteins. Handbook of Experimental Pharmacology 2008184 207-260. (https://doi.org/10.1007/978-3-540-74805-2_8)

7 Neylon CB, Nickashin A, Little PJ, Tkachuk VA \& Bobik A. Thrombininduced $\mathrm{Ca} 2+$ mobilization in vascular smooth muscle utilizes a slowly ribosylating pertussis toxin-sensitive G protein. Evidence for the involvement of a $\mathrm{G}$ protein in inositol trisphosphate-dependent Ca2+ release. Journal of Biological Chemistry 1992267 7295-7302.

8 McCudden CR, Hains MD, Kimple RJ, Siderovski DP \& Willard FS \& Willard FSG-Protein Signaling. G-protein signaling: back to the future. Cellular and Molecular Life Sciences 200562 551-577. (https:// doi.org/10.1007/s00018-004-4462-3)

9 Daub H, Weiss FU, Wallasch C \& Ullrich A. Role of transactivation of the EGF receptor in signalling by G-protein-coupled receptors. Nature 1996379 557-560. (https://doi.org/10.1038/379557a0)

10 Waters CM, Connell MC, Pyne S \& Pyne NJ. c-Src is involved in regulating signal transmission from PDGFbeta receptor-GPCR(s) complexes in mammalian cells. Cellular Signalling 200517 263-277. (https://doi.org/10.1016/j.cellsig.2004.07.011)

11 Belcheva MM, Haas PD, Tan Y, Heaton VM \& Coscia CJ. The fibroblast growth factor receptor is at the site of convergence between mu-opioid receptor and growth factor signaling pathways in rat C6 glioma cells. Journal of Pharmacology and Experimental Therapeutics 2002303 909-918. (https://doi.org/10.1124/ jpet.102.038554)

12 Burch ML, Ballinger ML, Yang SN, Getachew R, Itman C, Loveland K, Osman N \& Little PJ. Thrombin stimulation of proteoglycan synthesis in vascular smooth muscle is mediated by PAR-1 transactivation of the transforming growth factor $\beta$ type I receptor. Journal of Biological Chemistry 2010285 26798-26805. (https://doi. org/10.1074/jbc.M109.092767)

13 Kamato D, Thach L, Getachew R, Burch M, Hollenberg MD, Zheng W, Little PJ \& Osman N. Protease activated receptor-1 mediated dual kinase receptor transactivation stimulates the expression of glycosaminoglycan synthesizing genes. Cellular Signalling 201628 110-119. (https://doi.org/10.1016/j. cellsig.2015.11.003)

14 Little PJ, Burch ML, Getachew R, Al-Aryahi S \& Osman N. Endothelin-1 stimulation of proteoglycan synthesis in vascular smooth muscle is mediated by endothelin receptor transactivation of the transforming growth factor-[beta] type I receptor. Journal of Cardiovascular Pharmacology 201056 360-368. (https://doi. org/10.1097/FJC.0b013e3181ee6811)

15 Sharifat N, Mohammad Zadeh G, Ghaffari MA, Dayati P, Kamato D, Little PJ \& Babaahmadi-Rezaei H. Endothelin-1 (ET-1) stimulates carboxy terminal Smad2 phosphorylation in vascular endothelial cells by a mechanism dependent on et receptors and de novo protein 
synthesis. Journal of Pharmacy and Pharmacology 201769 66-72. (https://doi.org/10.1111/jphp.12654)

16 Burch ML, Getachew R, Osman N, Febbraio MA \& Little PJ. Thrombin-mediated proteoglycan synthesis utilizes both proteintyrosine kinase and serine/threonine kinase receptor transactivation in vascular smooth muscle cells. Journal of Biological Chemistry 2013 288 7410-7419. (https://doi.org/10.1074/jbc.M112.400259)

17 Kamato D, Burch ML, Osman N, Zheng W \& Little PJ. Therapeutic implications of endothelin and thrombin G-protein-coupled receptor transactivation of tyrosine and serine/threonine kinase cell surface receptors. Journal of Pharmacy and Pharmacology 201365 465-473. (https://doi.org/10.1111/j.2042-7158.2012.01577.x)

18 Talati N, Kamato D, Piva TJ, Little PJ \& Osman N. Thrombin promotes PAI-1 expression and migration in keratinocytes via ERK dependent Smad linker region phosphorylation. Cellular Signalling 201847 37-43. (https://doi.org/10.1016/j.cellsig.2018.03.009)

19 Zeng SY, Chen X, Chen SR, Li Q, Wang YH, Zou J, Cao WW, Luo JN, Gao H \& Liu PQ. Upregulation of Nox4 promotes angiotensin II-induced epidermal growth factor receptor activation and subsequent cardiac hypertrophy by increasing ADAM17 expression. Canadian Journal of Cardiology 201329 1310-1319. (https://doi. org/10.1016/j.cjca.2013.04.026)

20 Holmstrom KM \& Finkel T. Cellular mechanisms and physiological consequences of redox-dependent signalling. Nature Reviews: Molecular Cell Biology 201415 411-421. (https://doi.org/10.1038/ nrm3801)

21 Binker MG, Binker-Cosen AA, Richards D, Oliver B \& CosenBinker LI. EGF promotes invasion by PANC-1 cells through Rac1/ ROS-dependent secretion and activation of MMP-2. Biochemical and Biophysical Research Communications 2009379 445-450. (https://doi. org/10.1016/j.bbrc.2008.12.080)

22 Mohamed R, Dayati P, Mehr RN, Kamato D, Seif F, BabaahmadiRezaei H \& Little PJ. Transforming growth factor-beta1 mediated CHST11 and CHSY1 mRNA expression is ROS dependent in vascular smooth muscle cells. Journal of Cell Communication and Signaling 2019 13 225-233. (https://doi.org/10.1007/s12079-018-0495-x)

23 Rhyu DY, Yang Y, Ha H, Lee GT, Song JS, Uh ST \& Lee HB. Role of reactive oxygen species in TGF- $\beta 1$-induced mitogen-activated protein kinase activation and epithelial-mesenchymal transition in renal tubular epithelial cells. Journal of the American Society of Nephrology 200516 667-675. (https://doi.org/10.1681/ASN.2004050425)

24 Miller FJ, Chu X, Stanic B, Tian X, Sharma RV, Davisson RL \& Lamb FS. A differential role for endocytosis in receptor-mediated activation of Nox1. Antioxidants and Redox Signaling 201012 583-593. (https://doi.org/10.1089/ars.2009.2857)

25 Wang D, Yu X, Cohen RA \& Brecher P. Distinct effects of $\mathrm{N}$-acetylcysteine and nitric oxide on angiotensin II-induced epidermal growth factor receptor phosphorylation and intracellular $\mathrm{Ca}(2+)$ levels. Journal of Biological Chemistry 2000275 12223-12230. (https://doi.org/10.1074/jbc.275.16.12223)

26 Balakumar P \& Jagadeesh GJCS. A century old renin-angiotensin system still grows with endless possibilities: AT1 receptor signaling cascades in cardiovascular physiopathology. Cellular Signalling 2014 26 2147-2160. (https://doi.org/10.1016/j.cellsig.2014.06.011)

27 Kunsch C \& Medford RMJCR. Oxidative stress as a regulator of gene expression in the vasculature. Circulation Research 199985 753-766. (https://doi.org/10.1161/01.res.85.8.753)

28 Finkel T. Signal transduction by reactive oxygen species. Journal of Cell Biology 2011194 7-15. (https://doi.org/10.1083/ jcb.201102095)

29 Forstermann U, Xia N \& Li HG. Roles of vascular oxidative stress and nitric oxide in the pathogenesis of atherosclerosis. Circulation Research 2017120 713-735. (https://doi.org/10.1161/ CIRCRESAHA.116.309326)

30 Zhang DX \& Gutterman DD. Mitochondrial reactive oxygen species-mediated signaling in endothelial cells. American Journal of
Physiology: Heart and Circulatory Physiology 2007292 H2023-H2031. (https://doi.org/10.1152/ajpheart.01283.2006)

31 Garrido AM \& Griendling KK. NADPH oxidases and angiotensin II receptor signaling. Molecular and Cellular Endocrinology 2009302 148-158. (https://doi.org/10.1016/j.mce.2008.11.003)

32 Griendling KK \& Ushio-Fukai M. Reactive oxygen species as mediators of angiotensin II signaling. Regulatory Peptides 200091 21-27. (https://doi.org/10.1016/S0167-0115(00)00136-1)

33 Lassegue B, San Martín A \& Griendling KK. Biochemistry, physiology, and pathophysiology of NADPH oxidases in the cardiovascular system. Circulation Research 2012110 1364-1390. (https://doi. org/10.1161/CIRCRESAHA.111.243972)

34 Drummond GR, Selemidis S, Griendling KK \& Sobey CG. Combating oxidative stress in vascular disease: NADPH oxidases as therapeutic targets. Nature Reviews Drug Discovery 201110 453-471. (https://doi. org/10.1038/nrd3403)

35 Brandes RP, Weissmann N \& Schroder K. Nox family NADPH oxidases: molecular mechanisms of activation. Free Radical Biology and Medicine 201476 208-226. (https://doi.org/10.1016/j. freeradbiomed.2014.07.046)

36 Konior A, Schramm A, Czesnikiewicz-Guzik M \& Guzik TJ. NADPH oxidases in vascular pathology. Antioxidants and Redox Signaling 2014 20 2794-2814. (https://doi.org/10.1089/ars.2013.5607)

37 Bedard K \& Krause KH. The NOX family of ROS-generating NADPH oxidases: physiology and pathophysiology. Physiological Reviews 2007 87 245-313. (https://doi.org/10.1152/physrev.00044.2005)

38 Lassegue B, Sorescu D, Yin Q, Zhang Y, Lambeth SLG \& Griendling KK. Novel gp91phox homologues in vascular smooth muscle cells. Circulation Research 200188 888-894.

39 Lassegue B \& Griendling KK. NADPH oxidases: functions and pathologies in the vasculature. Arteriosclerosis, Thrombosis, and Vascular Biology 201030 653-661. (https://doi.org/10.1161/ ATVBAHA.108.181610)

40 Cave AC, Brewer AC, Narayanapanicker A, Ray R, Grieve DJ, Walker S, Shah AM. NADPH oxidases in cardiovascular health and disease. Antioxidants and Redox Signaling 20068 691-728. (https:// doi.org/10.1089/ars.2006.8.691)

41 Lyle AN, Deshpande NN, Taniyama Y, Seidel-Rogol B, Pounkova L, Du P, Papaharalambus C, Lassègue B \& Griendling KK. Poldip2, a novel regulator of Nox4 and cytoskeletal integrity in vascular smooth muscle cells. Circulation Research 2009105 249-259. (https:// doi.org/10.1161/CIRCRESAHA.109.193722)

42 Krause KH. Tissue distribution and putative physiological function of NOX family NADPH oxidases. Japanese Journal of Infectious Diseases 200457 S28-S29.

43 Touyz RM. Reactive oxygen species and angiotensin II signaling in vascular cells - implications in cardiovascular disease. Brazilian Journal of Medical and Biological Research 200437 1263-1273. (https:// doi.org/10.1590/s0100-879x2004000800018)

44 Zafari AM, Ushio-Fukai M, Akers M, Yin Q, Shah A, Harrison DG, Taylor WR \& Griendling KK. Novel role of NADH/NADPH oxidasederived hydrogen peroxide in angiotensin II-induced hypertrophy of rat vascular smooth muscle cells. Hypertension 199832 488-495. (https://doi.org/10.1161/01.hyp.32.3.488)

45 Darley-Usmar V, Wiseman H \& Halliwell B. Nitric oxide and oxygen radicals: a question of balance. FEBS Letters 1995369 131-135. (https://doi.org/10.1016/0014-5793(95)00764-z)

46 Winterbourn CC. The biological chemistry of hydrogen peroxide. Methods in Enzymology: Elsevier 2013528 3-25. (https://doi. org/10.1016/B978-0-12-405881-1.00001-X)

47 Cai D, Yuan M, Frantz DF, Melendez PA, Hansen L, Lee J \& Shoelson SE. Local and systemic insulin resistance resulting from hepatic activation of IKK-beta and NF-kappaB. Nature Medicine 2005 11 183-190. (https://doi.org/10.1038/nm1166)

48 Byon $\mathrm{CH}$, Heath JM \& Chen Y. Redox signaling in cardiovascular pathophysiology: a focus on hydrogen peroxide and vascular 
smooth muscle cells. Redox Biology 20169 244-253. (https://doi. org/10.1016/j.redox.2016.08.015)

49 Bayr H. Reactive oxygen species. Critical Care Medicine 200533 S498-S501. (https://doi.org/10.1097/01.CCM.0000186787.64500.12)

50 Thannickal VJ \& Fanburg BL. Reactive oxygen species in cell signaling. American Journal of Physiology: Lung Cellular and Molecular Physiology 2000279 L1005-L1028. (https://doi.org/10.1152/ ajplung.2000.279.6.L1005)

51 Brieger K, Schiavone S, Miller FJ. \& Krause KH. Reactive oxygen species: from health to disease. Swiss Medical Weekly 2012142 w13659. (https://doi.org/10.4414/smw.2012.13659)

52 Gupta RK, Patel AK, Shah N, Chaudhary AK, Jha UK, Yadav UC, Gupta PK \& Pakuwal U. Oxidative stress and antioxidants in disease and cancer: a review. Asian Pacific Journal of Cancer Prevention 2014 15 4405-4409. (https://doi.org/10.7314/apjcp.2014.15.11.4405)

53 Poljsak B, Suput D \& Milisav I. Achieving the balance between ROS and antioxidants: when to use the synthetic antioxidants. Oxidative Medicine and Cellular Longevity 20132013 956792. (https://doi. org/10.1155/2013/956792)

54 Griendling KK, Minieri CA, Ollerenshaw JD \& Alexander RW Angiotensin II stimulates NADH and NADPH oxidase activity in cultured vascular smooth muscle cells. Circulation Research $1994 \mathbf{7 4}$ 1141-1148. (https://doi.org/10.1161/01.res.74.6.1141)

55 Kaneyuki U, Ueda S, Yamagishi S, Kato S, Fujimura T, Shibata R, Hayashida A, Yoshimura J, Kojiro M, Oshima K, et al. Pitavastatin inhibits lysophosphatidic acid-induced proliferation and monocyte chemoattractant protein-1 expression in aortic smooth muscle cells by suppressing Rac-1-mediated reactive oxygen species generation. Vascular Pharmacology 200746 286-292. (https://doi.org/10.1016/j. vph.2006.11.002)

56 Daou GB \& Srivastava AK. Reactive oxygen species mediate endothelin-1-induced activation of ERK1/2, PKB, and Pyk2 signaling, as well as protein synthesis, in vascular smooth muscle cells. Free Radical Biology and Medicine 200437 208-215. (https://doi. org/10.1016/j.freeradbiomed.2004.04.018)

57 Gorlach A, Diebold I, Schini-Kerth VB, Berchner-Pfannschmidt U, Roth U, Brandes RP, Kietzmann T \& Busse R. Thrombin activates the hypoxia-inducible factor-1 signaling pathway in vascular smooth muscle cells: role of the p22(phox)-containing NADPH oxidase. Circulation Research 200189 47-54. (https://doi.org/10.1161/ hh1301.092678)

58 Schieber M \& Chandel NS. ROS function in redox signaling and oxidative stress. Current Biology 201424 R453-R462. (https://doi org/10.1016/j.cub.2014.03.034)

59 Nishida M, Maruyama Y, Tanaka R, Kontani K, Nagao T \& Kurose H. G alpha(i) and G alpha(o) are target proteins of reactive oxygen species. Nature 2000408 492-495. (https://doi. org/10.1038/35044120)

60 Aikawa R, Komuro I, Yamazaki T, Zou Y, Kudoh S, Tanaka M, Shiojima I, Hiroi Y \& Yazaki Y. Oxidative stress activates extracellular signal-regulated kinases through Src and Ras in cultured cardiac myocytes of neonatal rats. Journal of Clinical Investigation $1997 \mathbf{1 0 0}$ 1813-1821. (https://doi.org/10.1172/JCI119709)

61 Touyz RM \& Schiffrin EL. Ang II-stimulated superoxide production is mediated via phospholipase D in human vascular smooth muscle cells. Hypertension 199934 976-982. (https://doi.org/10.1161/01. hyp.34.4.976)

62 Gupte SA, Kaminski PM, George S, Kouznestova L, Olson SC, Mathew R, Hintze TH \& Wolin MS. Peroxide generation by p47phoxSrc activation of Nox 2 has a key role in protein kinase C-induced arterial smooth muscle contraction. American Journal of Physiology: Heart and Circulatory Physiology 2009296 H1048-H1057. (https://doi. org/10.1152/ajpheart.00491.2008)

63 Touyz RM \& Berry C. Recent advances in angiotensin II signaling. Brazilian Journal of Medical and Biological Research 200235 1001-1015. (https://doi.org/10.1590/s0100-879x2002000900001)
64 Bonventre JV. Phospholipase A2 and signal transduction. Journal of the American Society of Nephrology 19923 128-150.

65 Clempus RE \& Griendling KK. Reactive oxygen species signaling in vascular smooth muscle cells. Cardiovascular Research 200671 216-225. (https://doi.org/10.1016/j.cardiores.2006.02.033)

66 Lin CH, Cheng HW, Hsu MJ, Chen MC, Lin CC \& Chen BC. c-Src mediates thrombin-induced NF- $\kappa \mathrm{B}$ activation and IL-8/CXCL8 expression in lung epithelial cells. Journal of Immunology $2006 \mathbf{1 7 7}$ 3427-3438. (https://doi.org/10.4049/jimmunol.177.5.3427)

67 El-Benna J, Dang PM, Gougerot-Pocidalo MA, Marie JC \& BrautBoucher F. p47phox, the phagocyte NADPH oxidase/NOX2 organizer: structure, phosphorylation and implication in diseases. Experimental and Molecular Medicine 200941 217-225. (https://doi org/10.3858/emm.2009.41.4.058)

68 Meijles DN, Fan LM, Howlin BJ \& Li JM. Molecular insights of $\mathrm{p} 47$ phox phosphorylation dynamics in the regulation of NADPH oxidase activation and superoxide production. Journal of Biological Chemistry 2014289 22759-22770. (https://doi.org/10.1074/jbc. M114.561159)

69 Touyz RM \& Briones AM. Reactive oxygen species and vascular biology: implications in human hypertension. Hypertension Research 201134 5-14. (https://doi.org/10.1038/hr.2010.201)

70 Citri A \& Yarden Y. EGF-ERBB signalling: towards the systems level. Nature Reviews: Molecular Cell Biology 20067 505-516. (https://doi. org/10.1038/nrm1962)

71 Mitsudomi T \& Yatabe Y. Epidermal growth factor receptor in relation to tumor development: EGFR gene and cancer. FEBS Journal 2010277 301-308. (https://doi.org/10.1111/j.17424658.2009.07448.x)

72 Bae YS, Kang SW, Seo MS, Baines IC, tekle E, Chock PB \& Rhee SG. Epidermal growth factor (EGF)-induced generation of hydrogen peroxide. Role in EGF receptor-mediated tyrosine phosphorylation. Journal of Biological Chemistry 1997272 217-221. (https://doi. org/10.1074/jbc.272.1.217)

73 Seshiah PN, Weber DS, Rocic P, Valppu L, Taniyama Y \& Griendling KK. Angiotensin II stimulation of NAD(P)H oxidase activity: upstream mediators. Circulation Research 200291 406-413. (https://doi.org/10.1161/01.res.0000033523.08033.16)

74 Huo Y, Qiu WY, Pan Q, Yao YF, Xing K \& Lou MF. Reactive oxygen species (ROS) are essential mediators in epidermal growth factor (EGF)-stimulated corneal epithelial cell proliferation, adhesion, migration, and wound healing. Experimental Eye Research 200989 876-886. (https://doi.org/10.1016/j.exer.2009.07.012)

75 Dong J, Ramachandiran S, Tikoo K, Jia Z, Lau SS \& Monks TJ. EGFR-independent activation of p38 MAPK and EGFR-dependent activation of ERK1/2 are required for ROS-induced renal cell death. American Journal of Physiology: Renal Physiology 2004287 F1049-F1058. (https://doi.org/10.1152/ajprenal.00132.2004)

76 Svegliati S, Cancello R, Sambo P, Luchetti M, Paroncini P, Orlandini G, Discepoli G, Paterno R, Santillo M, Cuozzo C, et al. Platelet-derived growth factor and reactive oxygen species (ROS) regulate Ras protein levels in primary human fibroblasts via ERK1/2. Amplification of ROS and Ras in systemic sclerosis fibroblasts. Journal of Biological Chemistry $200528036474-36482$. (https://doi. org/10.1074/jbc.M502851200)

77 Kamata H, Honda S-I, Maeda S, Chang L, Hirata H \& Karin M. Reactive oxygen species promote TNF $\alpha$-induced death and sustained JNK activation by inhibiting MAP kinase phosphatases. Cell 2005 120 649-661. (https://doi.org/10.1016/j.cell.2004.12.041)

78 Liu R-M, Choi J, Wu J-H, Gaston-Pravia KA, Lewis KM, Brand JD, Mochel NR, Krzywanski DM, Lambeth JD \& Hagood JS. Oxidative modification of nuclear mitogen activated protein kinase phosphatase 1 is involved in transforming growth factor beta1induced expression of plasminogen activator inhibitor 1 in fibroblasts. Journal of Biological Chemistry 2010285 16239-16247. (https://doi.org/10.1074/jbc.M110.111732) 
79 Wentworth CC, Alam A, Jones RM, Nusrat A \& Neish AS. Enteric commensal bacteria induce extracellular signal-regulated kinase pathway signaling via formyl peptide receptor-dependent redox modulation of dual specific phosphatase 3. Journal of Biological Chemistry 2011286 38448-38455. (https://doi.org/10.1074/jbc. M111.268938)

80 Dong JY, Opresko LK, Dempsey PJ, Lauffenburger DA, Coffey RJ $\&$ Wiley HS. Metalloprotease-mediated ligand release regulates autocrine signaling through the epidermal growth factor receptor. PNAS 199996 6235-6240. (https://doi.org/10.1073/pnas.96.11.6235)

81 Prenzel N, Zwick E, Daub H, Leserer M, Abraham R, Wallasch C \& Ullrich A. EGF receptor transactivation by G-protein-coupled receptors requires metalloproteinase cleavage of proHB-EGF. Nature 1999402 884-888. (https://doi.org/10.1038/47260)

82 Cunnick JM, Dorsey JF, Standley T, Turkson J, Kraker AJ, Fry DW, Jove R \& Wu J. Role of tyrosine kinase activity of epidermal growth factor receptor in the lysophosphatidic acid-stimulated mitogenactivated protein kinase pathway. Journal of Biological Chemistry 1998 273 14468-14475. (https://doi.org/10.1074/jbc.273.23.14468)

83 Fan C, Katsuyama M, Nishinaka T \& Yabe-Nishimura C. Transactivation of the EGF receptor and a PI3 kinase-ATF-1 pathway is involved in the upregulation of NOX1, a catalytic subunit of NADPH oxidase. FEBS Letters 2005579 1301-1305. (https://doi. org/10.1016/j.febslet.2005.01.021)

84 Frank GD \& Eguchi S. Activation of tyrosine kinases by reactive oxygen species in vascular smooth muscle cells: significance and involvement of EGF receptor transactivation by angiotensin II. Antioxidants and Redox Signaling 20035 771-780. (https://doi. org/10.1089/152308603770380070)

85 Jagadeesha DK, Takapoo M, Banfi B, Bhalla RC \& Miller FJ. Nox1 transactivation of epidermal growth factor receptor promotes $\mathrm{N}$-cadherin shedding and smooth muscle cell migration. Cardiovascular Research 201293 406-413. (https://doi.org/10.1093/ cvr/cvr308)

86 Seshiah PN, Weber DS, Rocic P, Valppu L, Taniyama Y \& Griendling KK. Angiotensin II stimulation of NAD(P)H oxidase activity: upstream mediators. Circulation Research 200291 406-413. (https://doi.org/10.1161/01.res.0000033523.08033.16)

87 Iadecola C \& Gorelick PB. Hypertension, angiotensin, and stroke: beyond blood pressure. Stroke 200435 348-350. (https://doi. org/10.1161/01.STR.0000115162.16321.AA)

88 Giannoni E \& Chiarugi P. Redox circuitries driving Src regulation. Antioxidants and Redox Signaling 201420 2011-2025. (https://doi. org/10.1089/ars.2013.5525)

89 Biscardi JS, Maa MC, Tice DA, Cox ME, Leu TH \& Parsons SJ. c-Srcmediated phosphorylation of the epidermal growth factor receptor on Tyr845 and Tyr1101 is associated with modulation of receptor function. Journal of Biological Chemistry 1999274 8335-8343. (https://doi.org/10.1074/jbc.274.12.8335)

90 Ushio-Fukai M, Hilenski L, Santanam N, Becker PL, Ma Y, Griendling KK \& Alexander RW. Cholesterol depletion inhibits epidermal growth factor receptor transactivation by angiotensin II in vascular smooth muscle cells: role of cholesterol-rich microdomains and focal adhesions in angiotensin II signaling. Journal of Biological Chemistry 2001276 48269-48275. (https://doi.org/10.1074/jbc. M105901200)

91 Frank GD, Eguchi S, Yamakawa T, Tanaka S, Inagami T \& Motley ED. Involvement of reactive oxygen species in the activation of tyrosine kinase and extracellular signal-regulated kinase by angiotensin II 1. Endocrinology 2000141 3120-3126. (https://doi.org/10.1210/ endo.141.9.7630)

92 Bourmoum M, Charles R \& Claing A. The GTPase ARF6 controls ROS production to mediate angiotensin II-induced vascular smooth muscle cell proliferation. PLOS ONE 201611 e0148097. (https://doi. org/10.1371/journal.pone.0148097)
93 Charles R, Namkung Y, Cotton M, Laporte SA \& Claing A. $\beta$-Arrestinmediated angiotensin II signaling controls the activation of ARF6 protein and endocytosis in migration of vascular smooth muscle cells. Journal of Biological Chemistry 2016291 3967-3981. (https:// doi.org/10.1074/jbc.M115.684357)

94 Zuo L, Ushio-Fukai M, Ikeda S, Hilenski L, Patrushev N \& Alexander RW. Caveolin-1 is essential for activation of Rac1 and NAD (P) H oxidase after angiotensin II type 1 receptor stimulation in vascular smooth muscle cells: role in redox signaling and vascular hypertrophy. Arteriosclerosis, Thrombosis, and Vascular Biology 200525 1824-1830. (https://doi.org/10.1161/01.ATV.0000175295.09607.18)

95 Kamato D, Burch ML, Piva TJ, Rezaei HB, Rostam MA, Xu S, Zheng W, Little PJ \& Osman N. Transforming growth factorbeta signalling: role and consequences of Smad linker region phosphorylation. Cellular Signalling 201325 2017-2024. (https://doi. org/10.1016/j.cellsig.2013.06.001)

96 Derynck R \& Zhang YE. Smad-dependent and Smad-independent pathways in TGF-beta family signalling. Nature 2003425 577-584. (https://doi.org/10.1038/nature02006)

97 Kamato D, Rostam MA, Piva TJ, Babaahmadi Rezaei H, Getachew R, Thach L, Bernard R, Zheng W, Little PJ \& Osman N. Transforming growth factor beta-mediated site-specific Smad linker region phosphorylation in vascular endothelial cells. Journal of Pharmacy and Pharmacology 201466 1722-1733. (https://doi.org/10.1111/ jphp.12298)

98 Rostam MA, Kamato D, Piva TJ, Zheng W, Little PJ \& Osman N. The role of specific Smad linker region phosphorylation in TGF-beta mediated expression of glycosaminoglycan synthesizing enzymes in vascular smooth muscle. Cellular Signalling 201628 956-966. (https://doi.org/10.1016/j.cellsig.2016.05.002)

99 Rostam MA, Shajimoon A, Kamato D, Mitra P, Piva TJ, Getachew R, Cao Y, Zheng W, Osman N \& Little PJ. Flavopiridol inhibits TGF-beta-stimulated biglycan synthesis by blocking linker region phosphorylation and nuclear translocation of Smad2. Journal of Pharmacology and Experimental Therapeutics 2018365 156-164. (https://doi.org/10.1124/jpet.117.244483)

100 Michaeloudes C, Sukkar MB, Khorasani NM, Bhavsar PK \& Chung KF. TGF-beta regulates Nox4, MnSOD and catalase expression, and IL-6 release in airway smooth muscle cells. American Journal of Physiology: Lung Cellular and Molecular Physiology 2011300 L295-L304. (https:// doi.org/10.1152/ajplung.00134.2010)

101 Thannickal VJ \& Fanburg BL. Activation of an H2O2-generating NADH oxidase in human lung fibroblasts by transforming growth factor beta 1. Journal of Biological Chemistry $199527030334-30338$. (https://doi.org/10.1074/jbc.270.51.30334)

102 Albright CD, Salganik RI, Craciunescu CN, Mar MH \& Zeisel SH. Mitochondrial and microsomal derived reactive oxygen species mediate apoptosis induced by transforming growth factor-beta1 in immortalized rat hepatocytes. Journal of Cellular Biochemistry $2003 \mathbf{8 9}$ 254-261. (https://doi.org/10.1002/jcb.10498)

103 Hiraga R, Kato M, Miyagawa S \& Kamata T. Nox4-derived ROS signaling contributes to TGF-beta-induced epithelial-mesenchymal transition in pancreatic cancer cells. Anticancer Research 201333 4431-4438.

104 Sturrock A, Cahill B, Norman K, Huecksteadt TP, Hill K, Sanders K, Karwande SV, Stringham JC, Bull DA, Gleich M, et al. Transforming growth factor- $\beta 1$ induces Nox 4 NAD(P)H oxidase and reactive oxygen species-dependent proliferation in human pulmonary artery smooth muscle cells. American Journal of Physiology: Lung Cellular and Molecular Physiology 2006290 L661-L673. (https://doi.org/10.1152/ ajplung.00269.2005)

105 Yeh Y-H, Kuo C-T, Chang G-J, Qi X-Y, Nattel S \& Chen W-J. Nicotinamide adenine dinucleotide phosphate oxidase 4 mediates the differential responsiveness of atrial versus ventricular fibroblasts to transforming growth factor- $\beta$ clinical perspective. Circulation:
(C) 2019 The authors Published by Bioscientifica Ltd
This work is licensed under a Creative Commons Attribution-NonCommercial-NoDerivatives 4.0 International License. ded from Bioscientifica com at 04/26/2023 09:46:44AM 
Arrhythmia and Electrophysiology 20136 790-798. (https://doi. org/10.1161/CIRCEP.113.000338)

106 Rezaei HB, Kamato D, Ansari G, Osman N \& Little PJ. Cell biology of Smad2/3 linker region phosphorylation in vascular smooth muscle. Clinical and Experimental Pharmacology and Physiology 201239 661-667. (https://doi.org/10.1111/j.1440-1681.2011.05592.x)

107 Zhang W, Zeng Q, Xu Y, Ying H, Zhou W, Cao Q \& Zhou W. Exome sequencing identified a novel SMAD2 mutation in a Chinese family with early onset aortic aneurysms. Clinica Chimica Acta: International Journal of Clinical Chemistry 2017468 211-214. (https://doi. org/10.1016/j.cca.2017.03.007)

108 Foo NP, Lin SH, Lee YH, Wu MJ \& Wang YJ. $\alpha$-Lipoic acid inhibits liver fibrosis through the attenuation of ROS-triggered signaling in hepatic stellate cells activated by PDGF and TGF- $\beta$. Toxicology 2011 282 39-46. (https://doi.org/10.1016/j.tox.2011.01.009)

109 Ismail S, Sturrock A, Wu P, Cahill B, Norman K, Huecksteadt T, Sanders K, Kennedy T \& Hoidal J. NOX4 mediates hypoxia-induced proliferation of human pulmonary artery smooth muscle cells: the role of autocrine production of transforming growth factor\{beta\}1 and insulin-like growth factor binding protein-3. American Journal of Physiology: Lung Cellular and Molecular Physiology 2009296 L489-L499. (https://doi.org/10.1152/ajplung.90488.2008)

110 Jernigan NL, Walker BR \& Resta TC. Reactive oxygen species mediate RhoA/Rho kinase-induced $\mathrm{Ca} 2+$ sensitization in pulmonary vascular smooth muscle following chronic hypoxia. American Journal of Physiology: Lung Cellular and Molecular Physiology 2008295 L515-L529. (https://doi.org/10.1152/ ajplung.00355.2007)

111 Lynch JR, Yi H, Casolari DA, Voli F, Gonzales-Aloy E, Fung TK, Liu B, Brown A, Liu T, Haber M, et al. Gaq signaling is required for the maintenance of MLL-AF9-induced acute myeloid leukemia. Leukemia 201630 1745-1748. (https://doi.org/10.1038/leu.2016.24)

112 Mori S, Matsuzaki K, Yoshida K, Furukawa F, Tahashi Y, Yamagata H, Sekimoto G, Seki T, Matsui H, Nishizawa M, et al. TGF-beta and HGF transmit the signals through JNK-dependent Smad2/3 phosphorylation at the linker regions. Oncogene 200423 7416-7429. (https://doi.org/10.1038/sj.onc.1207981)

113 Harrison D, griendling KK, landmesser U, Hornig B \& Drexler H. Role of oxidative stress in atherosclerosis. American Journal of Cardiology 200391 7A-11A. (https://doi.org/10.1016/s0002-9149(02)03144-2)

114 Lusis AJ, Mar R \& Pajukanta P. Genetics of Atherosclerosis. Annual Reviews of Genomics and Human Genetics 20045 189-218. (https://doi. org/10.1146/annurev.genom.5.061903.175930)

115 Griendling KK, Sorescu D, Lassegue B \& Ushio-Fukai M. Modulation of protein kinase activity and gene expression by reactive oxygen species and their role in vascular physiology and pathophysiology. Arteriosclerosis, Thrombosis, and Vascular Biology 200020 2175-2183. (https://doi.org/10.1161/01.ATV.20.10.2175)

116 Nigro J, Osman N, Dart AM \& Little PJ. Insulin resistance and atherosclerosis. Endocrine Reviews 200627 242-259. (https://doi. org/10.1210/er.2005-0007)

117 Zhang Y, Koradia A, Kamato D, Popat A, Little PJ \& Ta HT. Treatment of atherosclerotic plaque: perspectives on theranostics. Journal of Pharmacy and Pharmacology 201971 1029-1043. (https://doi. org/10.1111/jphp.13092)
118 Kattoor AJ, Pothineni NVK, Palagiri D \& Mehta JL. Oxidative stress in atherosclerosis. Current Atherosclerosis Reports 201719 42. (https:// doi.org/10.1007/s11883-017-0678-6)

119 Steinhubl SR. Why have antioxidants failed in clinical trials? American Journal of Cardiology 2008101 14D-19D. (https://doi. org/10.1016/j.amjcard.2008.02.003)

120 Heart Outcomes Prevention Evaluation Study Investigators, Yusuf S, Dagenais G, Pogue J, Bosch J \& Sleight P. Vitamin E supplementation and cardiovascular events in high-risk patients. New England Journal of Medicine 2000342 154-160. (https://doi.org/10.1056/ NEJM200001203420302)

121 Stocker R \& Keaney JF. New insights on oxidative stress in the artery wall. Journal of Thrombosis and Haemostasis 20053 1825-1834. (https://doi.org/10.1111/j.1538-7836.2005.01370.x)

122 Chaplin R, Thach L, Hollenberg MD, Cao Y, Little PJ \& Kamato D. Insights into cellular signalling by $\mathrm{G}$ protein coupled receptor transactivation of cell surface protein kinase receptors. Journal of Cell Communication and Signaling 201711 117-125. (https://doi. org/10.1007/s12079-017-0375-9)

123 Afroz R, Cao Y, Rostam MA, Ta H, Xu S, Zheng W, Osman N, Kamato D \& Little PJ. Signalling pathways regulating galactosaminoglycan synthesis and structure in vascular smooth muscle: implications for lipoprotein binding and atherosclerosis. Pharmacology and Therapeutics 2018187 88-97. (https://doi. org/10.1016/j.pharmthera.2018.02.005)

124 Kamato D, Burch M, Zhou Y, Mohamed R, Stow JL, Osman N, Zheng W \& Little PJ. Individual Smad2 linker region phosphorylation sites determine the expression of proteoglycan and glycosaminoglycan synthesizing genes. Cellular Signalling 201953 365-373. (https://doi.org/10.1016/j.cellsig.2018.11.005)

125 Getachew R, Ballinger ML, Burch ML, Reid JJ, Khachigian LM, Wight TN, Little PJ \& Osman N. PDGF beta-receptor kinase activity and ERK1/2 mediate glycosaminoglycan elongation on biglycan and increases binding to LDL. Endocrinology $20101514356-4367$. (https://doi.org/10.1210/en.2010-0027)

126 Kamato D, Babaahmadi Rezaei H, Getachew R, Thach L, Guidone D, Osman N, Roufogalis B, Duke CC, Tran VH, Zheng W, et al. (S)-[6]Gingerol inhibits TGF-beta-stimulated biglycan synthesis but not glycosaminoglycan hyperelongation in human vascular smooth muscle cells. Journal of Pharmacy and Pharmacology 201365 1026-1036. (https://doi.org/10.1111/jphp.12060)

127 Kamato D, Bhaskarala VV, Mantri N, Oh TG, Ling D, Janke R, Zheng W, Little PJ \& Osman N. RNA sequencing to determine the contribution of kinase receptor transactivation to $G$ protein coupled receptor signalling in vascular smooth muscle cells. PLOS ONE 2017 12 e0180842. (https://doi.org/10.1371/journal.pone.0180842)

128 Little PJ, Hollenberg MD, Kamato D, Thomas W, Chen J, Wang T, Zheng W \& Osman N. Integrating the GPCR transactivationdependent and biased signalling paradigms in the context of PAR-1 signalling. British Journal of Pharmacology 2016173 2992-3000. (https://doi.org/10.1111/bph.13398)

129 Goszcz K, Deakin SJ, Duthie GG, Stewart D, Leslie SJ \& Megson IL. Antioxidants in cardiovascular therapy: panacea or false hope? Frontiers in Cardiovascular Medicine 20152 29. (https://doi. $\operatorname{org} / 10.3389 /$ fcvm.2015.00029)

Received in final form 7 July 2019

Accepted 23 July 2019

Accepted Preprint published online 23 July 2019 https://vb.bioscientifica.com

https://doi.org/10.1530/VB-18-0004 (c) 2019 The authors Published by Bioscientifica Ltd
This work is licensed under a Creative Commons Attribution-NonCommercial-NoDerivatives 4.0 International License. ded from Bioscientifica com at 04/26/2023 09:46:44AM 